\title{
Moral Distress, Sign of Ethical Issues in the Practice of Oncology Nursing: Literature Review
}

\begin{abstract}
Thematic area: Chronic care.
Contribution to the discipline: The synthesis of the evidence that exists around the triggering factors of moral distress in oncology nurses, permits understanding how this phenomenon develops in the teams working with people with cancer and, thus, guide clinical nursing professionals and the nursing organizational leaders in investigating this problem, and in the development of interventions that protect the ethical exercise of the care practice.
\end{abstract}

\section{ABSTRACT}

Objective: To describe the factors that influence the emergence of moral distress in oncology nurses. Methodology: integrative review of the literature whose search will be performed in Web of Science databases, CINAHL (EBSCO), Scielo, Proquest, Pubmed and PsycInfo using the keywords moral distress and oncology nursing and their similes in Spanish, without restriction for years of publication until 2017. Results: The results of this review were grouped into three groups of factors each with subgroups: 1) Organizational factors: ethical climate, evasive culture and resources for ethics delivered by the organization. 2) Particular clinical situations: pain management, information delivery, futile treatment, and assistance to the patient and their family in the process of death, 3) Interpersonal relationships: poor communication, power relations, trust in the team's competence. Conclusion: the three factors described are triggers of moral distress in oncology nurses. When there are ethical problems and the nurses do not participate in the deliberation process, these problems can be hidden and be normalized, which can diminish the moral sensitivity of the professionals, as well as the possibility of acting as moral agents.

\section{KEYWORDS (SOURCE: DeCS)}

Moral distress; oncology nursing; ethics; ethical climate; ethical issues; interprofessional relations.

DOI: 10.5294/aqui.2019.19.1.3

To reference this article / Para citar este artículo / Para citar este artigo

Vargas I, Concha CA. Moral Distress, Sign of Ethical Issues in the Practice of Oncology Nursing: Literature Review. Aquichan 2019; 19(1): el913. DOI: 10.5294/aqui.2019.19.1.3

$1 \bowtie$ orcid.org/0000-0003-2756-7640. Escuela de Enfermería, Pontificia Universidad Católica de Chile, Chile. ivargase@uc.cl 


\section{Angustia moral, señal de problemas éticos en la práctica de enfermería oncológíca: revisión de literatura}

\section{RESUMEN}

Objetivo: describir los factores que influyen en el surgimiento de la angustia moral en enfermeras oncológicas. Metodología: revisión integradora de la literatura cuya búsqueda se realizó en las bases de datos Web of Science, CINAHL (EBSCO), Scielo, Proquest, Pubmed y PsycInfo, a partir del uso de las palabras clave moral distress y oncology nursing y sus símiles en español, sin restricción por años de publicación hasta 2017. Resultados: se clasificaron en tres grupos de factores, cada uno con subgrupos: 1) factores organizacionales: clima ético, cultura evasiva y los recursos para la ética que entrega la organización; 2) situaciones clínicas complejas: el manejo del dolor, la entrega de información, el tratamiento fútil, y la asistencia al paciente y su familia durante el proceso de muerte; 3) relaciones interpersonales: una comunicación deficiente, las relaciones de poder, la confianza en la competencia del equipo. Conclusión: los tres factores son desencadenantes de angustia moral en las enfermeras oncológicas. Cuando existen problemas éticos, y las enfermeras no participan del proceso de deliberación, estos pueden quedar ocultos y, así, disminuir la sensibilidad moral de los profesionales, así como la posibilidad de actuar como agentes morales. Es necesario explorar la relación entre la angustia moral y las implicancias en el cuidado del paciente.

PALABRAS CLAVE (FUENTE: DeCS)

Angustia moral; enfermería oncológica; clima ético; problemas éticos; relaciones interprofesionales. 


\section{Angústia moral, sinal de problemas éticos na prática de enfermagem oncológïca: revisão de literatura}

\section{RESUMO}

Objetivo: descrever os fatores que influenciam no surgimento da angústia moral em enfermeiras oncológicas. Metodologia: revisão integradora da literatura cuja pesquisa foi realizada nas bases de dados Web of Science, CINAHL (EBSCO), Scielo, Proquest, Pubmed e PsycInfo, a partir do uso das palavras-chave moral, distress e oncology nursing e seus pares em espanhol, sem restrição por ano de publicação até 2017. Resultados: criou-se três grupos de fatores, cada um deles com subgrupos: 1) fatores organizacionais - clima ético, cultura evasiva e recursos para a ética que a organização entrega; 2) situações clínicas complexas - 0 tratamento da dor, a entrega de informação, o tratamento fútil e a assistência ao paciente e à sua família durante o processo de morte; 3) relações interpessoais - uma comunicação deficiente, as relações de poder, a confiança na competência da equipe. Conclusão: os três fatores são desencadeantes de angústia moral nas enfermeiras oncológicas. Quando existem problemas éticos e as enfermeiras não participam do processo de deliberação, estes podem ficam ocultos e, assim, diminuir a sensibilidade moral dos profissionais, bem como a possibilidade de atuar como agentes morais. É necessário explorar a relação entre a angústia moral e suas implicações no cuidado do paciente.

\section{PALAVRAS-CHAVE (FONTE: DECS)}

Angústia moral; enfermagem; oncología; clima ético; problemas éticos; sensibilidade moral. 


\section{Introduction}

Clinical situations exist in which nursing professionals have a clear opinion of what is the morally correct course of an action, but the institutional or hierarchical structure often keeps them from deciding what should be their own moral actions; this experience is what Jameton denominates moral distress (1). Distress is something different from fear or uncertainty, given that it is related with the experience of freedom as possibility, that is, the faculty an individual has to act freely (2). Nursing professionals, as moral agents, have the possibility of choosing to do what is correct, but their election can be restricted by something external or internal, which generates in them a sense of powerlessness when not being able to act correctly (3). Hence, moral distress appears.

Literature describes moral distress as a current and important problem that affects patients in different health systems (47). This phenomenon has been explored in the area of critical care $(8-10)$ and has been described as a threat to the integrity of the nurses, as well as to the quality of patient care (11). Studying it is an opportunity to transform moral distress into moral resilience and to help nurses, and other health providers, to mitigate its effects, improve the ethical environment of the practice and quality in care (12).
The concept of moral distress has been discussed by different authors $(3,11,13,14)$, who are critical of the way this problem has been researched, given that errors have been detected in the objectives of the studies, as well as in the operationalization of the concept itself (14). Some suggest that research should focus on improving the quality of the moral decision, moral conduct, among others (11). However, recent studies propose rethinking the way it is being investigated and suggest that it is an opportunity to address its causes, its development, and its moral foundations (15).

Within the literature, the work by Barlem and Ramos (3) stands out, proposing a conceptual model (Figure 1) that explains the emergence and manifestations of moral distress. This model has as central point the moral deliberation process, which is an ethical approach where dialogue seeks to discuss rationally and reflect critically to reach an agreement (3). The deliberation process and the moral sensitivity permit seeing moral problems that could remain hidden and, therein, discuss the possible solutions or ways of coping with them within the health staff. In addition, the authors establish that multiple micro-spaces of power exist in which health professionals perform and develop their relational dynamics (3).

In the oncology area, this is a growing phenomenon with health staff caring for cancer patients (16-21). Among the motives

Figure 1. Conceptual model of moral distress by Barlem and Ramos

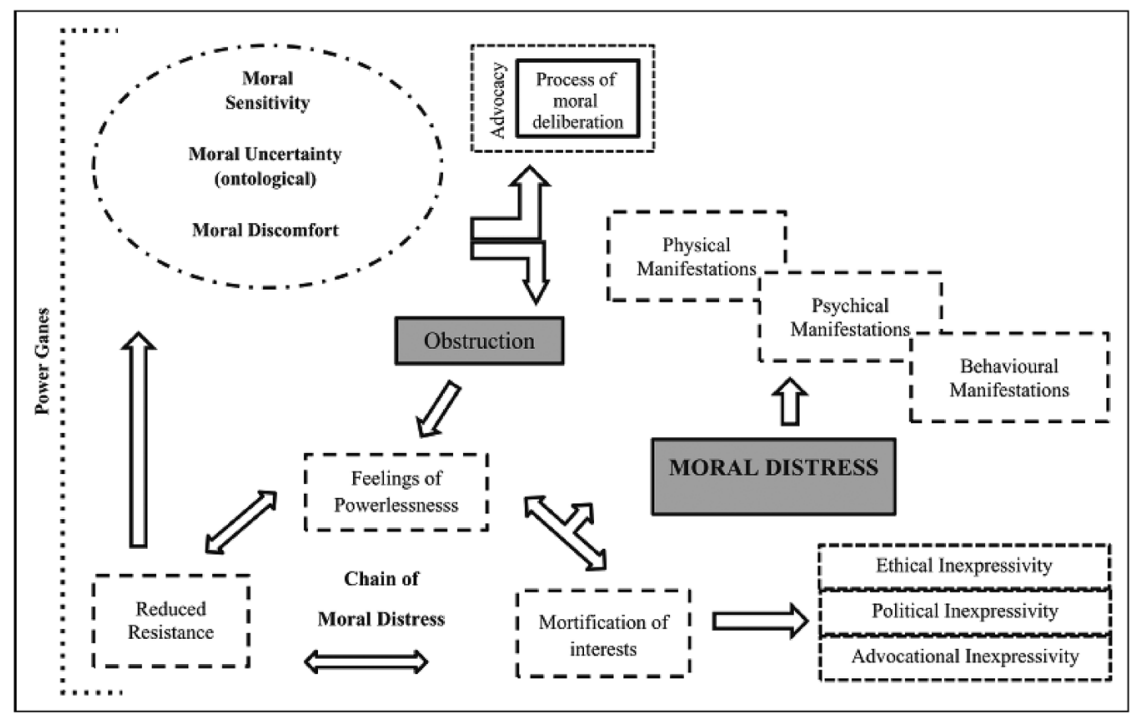

Source: Barlem ELD, Ramos FRS (3). 
for the emergence of moral distress in this area, ethical conflicts are highlighted associated with the use of advanced technology, both in relation with caring for patients, as with the treatments, entailing ethical challenges for nurses $(18,22,23)$, which are derived from the complex clinical situations they experience next to their patients. Due to the aforementioned, this literature review describes the factors that influence upon the emergence of moral distress in oncology nurses.

\section{Methodology}

The review was developed from the six stages proposed by Ganong (24):

1. Guiding question: What are the factors that influence upon the emergence of moral distress in oncology nurses? The search used key words in English: Moral distress, oncology nursing and their similes in Spanish.

2. Inclusion criteria: Articles, editorials and reflections related with moral distress in the area of oncology nursing. No restriction was applied for years of publication, given that it is a new theme of which no literature review was found encompassing the objective of this work. The study included articles in Spanish, English, and Portuguese and excluded those that do not address the phenomenon of moral distress explicitly or which were not related with oncology nursing.

3. The data were obtained from the databases Web of Science, EBSCO (CINAHL), Proquest Central, Pubmed, and PsycInfo, between August and December 2017. From the key words established in the different databases, 177 registries were found; both researchers selected the articles according to the title and abstract, and discriminated them from the objective of the document, and in contrast with the initial question of the review. Those not related with moral distress in oncology were excluded, as well as those from the area of palliative care and whose theme was clinical research, for a total of 38 registries (139 eliminated); and the duplicated registries (20 eliminated), for a total of 18 selected (Figure 2).

4. Each of the 18 articles selected was subjected to a critical reading using a process of abstraction, synthesis, and data analysis from the guide questions (Chart 1 ) to synthesize the information collected on moral distress in the area of nursing oncology.
Figure 2. Search strategy

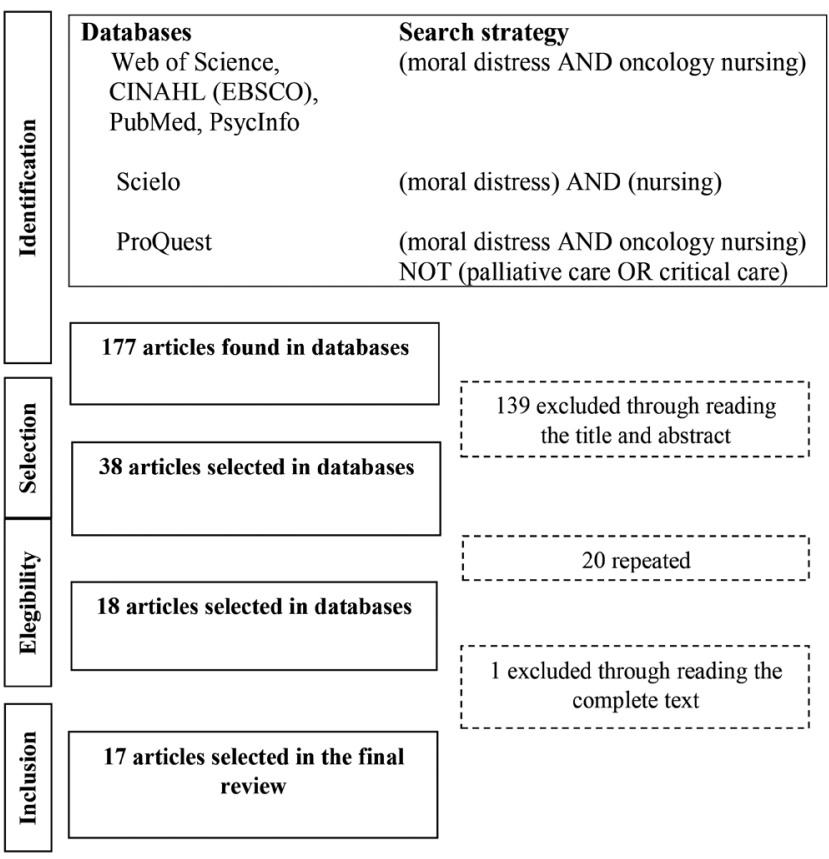

Source: Moher D, Liberati A, Tetzlaff J, Altman DG (25).

Chart 1: Guide questions to analyze the articles

How is moral distress measured?

What factors contribute to the development of moral distress in oncology nurses?

What factors slow down the development of moral distress in oncology nurses?

Source: Own elaboration.

In this process, the reviewers agreed on eliminating an article that did not deal specifically with moral distress; thus, leaving a total of 17 registries for this review. Both reviewers extracted from each of the articles the information corresponding to the factors that influence upon the emergence of 
moral distress and gathered this information into themes or subcategories that group the factors that influence - both favorably and unfavorably - the emergence of moral distress; in turn, this information was classified into three large categories (Figure 3).

5. To introduce the results, each of the categories was described according to the findings in the articles, and to discuss the results, the results obtained were contrasted and integrated with the model by Barlem and Ramos (3), when comparing the elements present in said model with the findings from this review, creating a new matrix to understand the phenomenon of moral distress in the area of oncology nursing (Figure 4).

\section{Results}

Of the 17 articles selected for this review, seven corresponded to qualitative studies $(22,23,26-30)$; six to quantitative studies $(16,31-35)$; two were reflections $(36,37)$; and two were editorials $(17,18)$ (Figure 3). Eighteen percent of the articles were published between 2006 and 2011, and 82\% between 2012 and 2016 (Figure 4). The studies were conducted in different countries: most of them from the United States and the rest from Europe, South America, and Asia (Figure 5).

Figure 3. Distribution according to the type of article

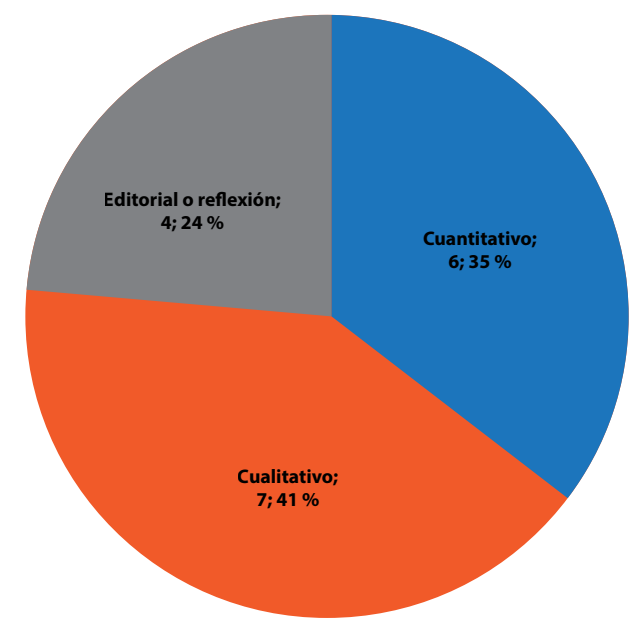

Source: Own elaboration.
Figure 4. Distribution by years of publication

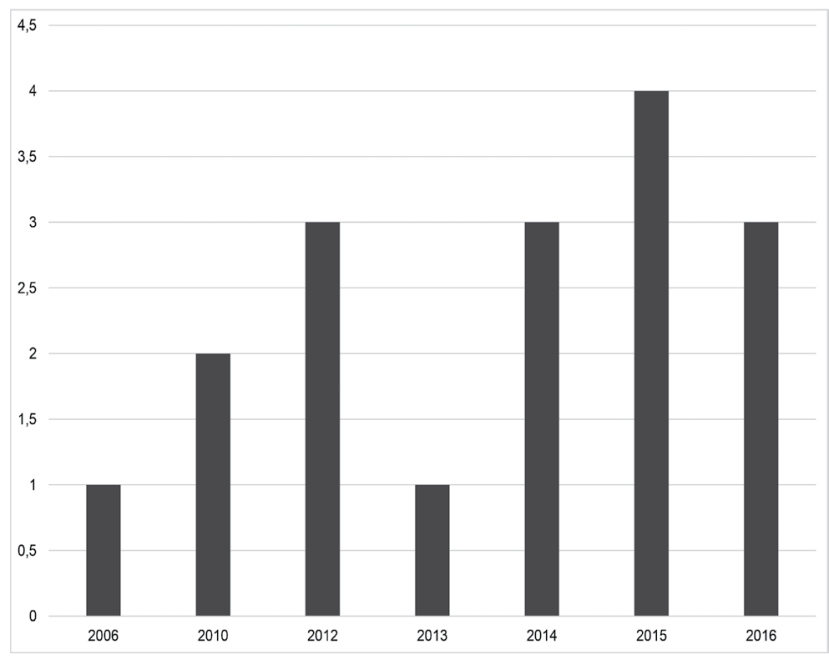

Source: Own elaboration.

Figure 5. Distribution of articles according to country

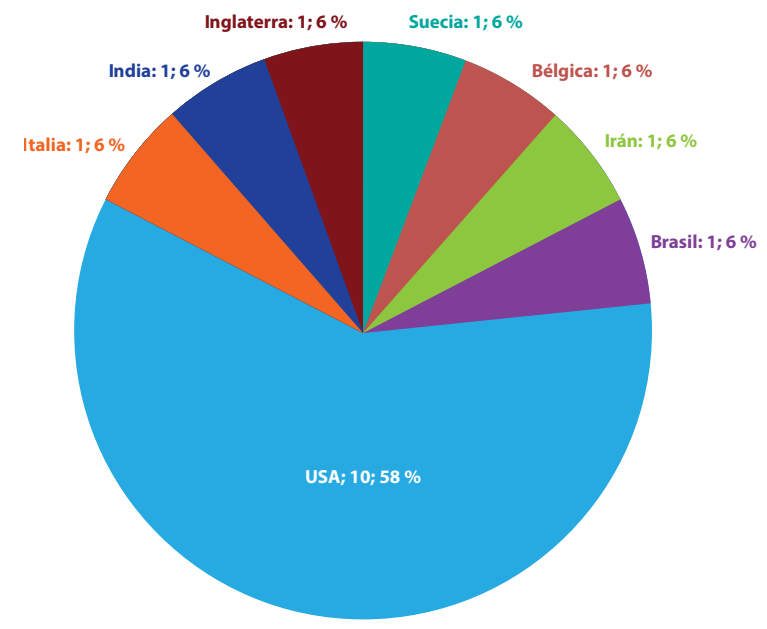

Source: Own elaboration.

Quantitative studies used the instrument Moral Distress Scale (MDS) (34) or the version Moral Distress Scale - Revised (MDS-R) $(31,35)$ to measure moral distress in nurses from the oncology area. Another study used the pediatric version of the MDS (MDS$\mathrm{PV})$ : the items in this scale differ from the MDS only in reference to pediatric subjects instead of adults (33). 
Table 1. Articles found in the literature on moral distress in oncology nursing

\begin{tabular}{|c|c|c|c|c|}
\hline Authors & Research focus & Study design & Sample & Summary of results \\
\hline $\begin{array}{c}\text { Ameri, } \\
\text { Safavibayatneed } \\
\text { and Kavousi (31) }\end{array}$ & $\begin{array}{l}\text { Assess the intensity and frequency } \\
\text { of moral distress and determine the } \\
\text { clinical situations that lead to moral } \\
\text { distress in oncology units. }\end{array}$ & $\begin{array}{l}\text { Quantitative } \\
\text { descriptive }\end{array}$ & 148 Nurses & $\begin{array}{l}\text { Most of the nurses had high to moderate scores of moral } \\
\text { distress. The nurses had experienced higher moral distress } \\
\text { in relation with the informed consent of the patients } \\
\text { regarding unnecessary tests during the last stages of life } \\
\text { of these patients. }\end{array}$ \\
\hline $\begin{array}{l}\text { Bartholdson } \\
\text { et al. (16) }\end{array}$ & $\begin{array}{l}\text { Describe the perceptions of the } \\
\text { hospital pediatric ethical climate among } \\
\text { health professionals caring for children } \\
\text { with cancer. }\end{array}$ & $\begin{array}{l}\text { Quantitative } \\
\text { descriptive }\end{array}$ & $\begin{array}{l}\text { Physicians }(\mathrm{n}=15) \\
\text { nurses }(\mathrm{n}=36) \\
\text { and nursing aides ( } \mathrm{n} \\
\quad=38)\end{array}$ & $\begin{array}{l}\text { A good ethical climate is a factor that could diminish moral } \\
\text { distress. }\end{array}$ \\
\hline $\begin{array}{l}\text { Bohnenkamp } \\
\text { et al. (32) }\end{array}$ & $\begin{array}{c}\text { Describe how a hospital nursing staff } \\
\text { addressed the ethical concerns and } \\
\text { the problems occurring in the surgical } \\
\text { oncology unit. }\end{array}$ & $\begin{array}{l}\text { Quantitative } \\
\text { descriptive }\end{array}$ & $\begin{array}{l}\text { Two surveys are } \\
\text { applied one year } \\
\text { apart in the same } \\
\text { place: } \mathrm{N}=19 \text { and } \mathrm{N} \\
\quad=22 \text { nurses. }\end{array}$ & $\begin{array}{c}\text { The clinical situations identified as morally distressing } \\
\text { and the most relevant were working with inadequate or } \\
\text { incompetent personnel (nursing or medical) and providing } \\
\text { (by the physician) inappropriate or inefficient care to the } \\
\text { patient. }\end{array}$ \\
\hline Sirilla (35) & $\begin{array}{l}\text { Explore the existence of moral distress } \\
\text { in oncology nurses. }\end{array}$ & $\begin{array}{l}\text { Quantitative } \\
\text { correlational }\end{array}$ & 73 oncology nurses. & $\begin{array}{l}\text { The type of unit and level of moral suffering were } \\
\text { correlated, finding an inverse relationship between the } \\
\text { level of education and moral distress. }\end{array}$ \\
\hline $\begin{array}{l}\text { Lazzarin et al. } \\
\text { (33) }\end{array}$ & $\begin{array}{l}\text { Translate from English into Italian } \\
\text { the pediatric version of the MDS and } \\
\text { MDS-PV. }\end{array}$ & $\begin{array}{l}\text { Quantitative } \\
\text { correlational }\end{array}$ & $\begin{array}{l}156 \text { oncology and } \\
\text { hematology nurses. }\end{array}$ & $\begin{array}{l}\text { The results confirm the validity of the MDS-PV to use this } \\
\text { scale on pediatric oncology nurses and describe the results } \\
\text { of the application of the scale. }\end{array}$ \\
\hline $\begin{array}{l}\text { Maningo-Salinas } \\
\quad \text { et al. (34) }\end{array}$ & $\begin{array}{l}\text { Examine the relation between the } \\
\text { levels of moral distress experienced by } \\
\text { oncology nurses and the probability of } \\
\text { their rotation intention. }\end{array}$ & $\begin{array}{l}\text { Quantitative } \\
\text { correlational } \\
\text { thesis }\end{array}$ & 180 oncology nurses. & $\begin{array}{c}\text { A higher level of moral distress was weakly correlated with } \\
\text { greater anticipated rotation. A higher level of perceived } \\
\text { organizational support was strongly correlated with lower } \\
\text { anticipated rotation. }\end{array}$ \\
\hline $\begin{array}{l}\text { Lievrouw et al. } \\
\quad(27)\end{array}$ & $\begin{array}{l}\text { Explore variations to confront moral } \\
\text { distress between physicians and } \\
\text { nurses in the oncology setting of a } \\
\text { university hospital. }\end{array}$ & Qualitative & $\begin{array}{l}18 \text { oncology nurses } \\
\text { with different levels of } \\
\text { experience. }\end{array}$ & $\begin{array}{l}\text { Moral distress was prolonged when it was accompanied } \\
\text { by emotional distress. The four dominant forms of coping } \\
\text { suggested the existence of a tendency to internalize or } \\
\text { externalize moral distress and a tendency to focus on } \\
\text { rational or experiential elements. }\end{array}$ \\
\hline Luz et al. (22) & $\begin{array}{l}\text { Know the ethical issues lived by } \\
\text { oncology nurses. }\end{array}$ & Qualitative & 18 nurses. & $\begin{array}{l}\text { Two categories related with the experience of ethical } \\
\text { issues: when reporting or not becomes a dilemma; } \\
\text { investing or not dilemma related to death, compromising } \\
\text { patient care. }\end{array}$ \\
\hline $\begin{array}{l}\text { Pavlish et al. } \\
\text { (29) }\end{array}$ & $\begin{array}{l}\text { Examine the challenges and postures } \\
\text { surrounding ethically difficult situations } \\
\text { in oncology practice. }\end{array}$ & $\begin{array}{l}\text { Qualitative, } \\
\text { ethnographic }\end{array}$ & 30 oncology nurses. & $\begin{array}{l}\text { Many health professionals remain silent regarding ethical } \\
\text { concerns until a precipitating crisis occurs and the ethical } \\
\text { issues can no longer be avoided. }\end{array}$ \\
\hline $\begin{array}{l}\text { Pavlish et al. } \\
\text { (23) }\end{array}$ & $\begin{array}{l}\text { Explore ethical conflicts in oncology } \\
\text { practice and the nature of the contexts } \\
\text { of medical care in which ethical } \\
\text { conflicts can be avoided or mitigated. }\end{array}$ & $\begin{array}{l}\text { Qualitative, } \\
\text { ethnographic }\end{array}$ & 30 oncology nurses. & $\begin{array}{l}\text { The majority of ethical conflicts refer to end-of-life complex } \\
\text { situations. Three factors were associated with ethical } \\
\text { conflicts: delaying or avoiding difficult conversations, } \\
\text { feeling divided between obligations in competence and } \\
\text { silencing of different moral perspectives. }\end{array}$ \\
\hline
\end{tabular}




\begin{tabular}{|c|c|c|c|c|}
\hline Authors & Research focus & Study design & Sample & Summary of results \\
\hline $\begin{array}{l}\text { Lebaron, Beck, } \\
\text { Black and Palat } \\
\qquad(26)\end{array}$ & $\begin{array}{c}\text { Explore the experience of moral } \\
\text { distress in oncology nurses and other } \\
\text { providers. }\end{array}$ & $\begin{array}{l}\text { Qualitative, } \\
\text { ethnographic }\end{array}$ & 37 oncology nurses. & $\begin{array}{l}\text { The participants described significant problems related } \\
\text { with the work, but the moral dimension of this distress was } \\
\text { less clear, given that some key aspects of moral distress } \\
\text { have limited applicability in settings where alternative } \\
\text { courses of action are unknown, or not feasible, and } \\
\text { where different social and cultural norms influence moral } \\
\text { sensitivity. }\end{array}$ \\
\hline Pye (30) & $\begin{array}{l}\text { Explore the perceptions of physicians } \\
\text { and nurses who work in a pediatric } \\
\text { oncology unit, their experiences and } \\
\text { feelings with respect to moral distress. }\end{array}$ & $\begin{array}{l}\text { Qualitative, } \\
\text { phenomenological }\end{array}$ & 4 nurses. & $\begin{array}{l}\text { Three themes were identified that expressed the } \\
\text { morally distressing experiences for the participants: the } \\
\text { importance of decision making processes, conflict on } \\
\text { the right to treatment and retention of treatment, and } \\
\text { communication within the staff. }\end{array}$ \\
\hline $\begin{array}{l}\text { Pavlish et al. } \\
\text { (28). }\end{array}$ & $\begin{array}{l}\text { Explore the experiences of oncology } \\
\text { nurses and other key players in } \\
\text { ethically difficult clinical situations. }\end{array}$ & $\begin{array}{l}\text { Qualitative, } \\
\text { ethnographic }\end{array}$ & 30 nurses. & $\begin{array}{l}\text { Nurses experienced six principal challenges to comply } \\
\text { their objectives: being the eyes and arms of the patient's } \\
\text { suffering; experiencing the precariousness of conflicting } \\
\text { obligations; navigating through the complexities of hope } \\
\text { and honesty; managing the urgency caused by waiting, } \\
\text { making efforts to find time and weigh the risks of speaking } \\
\text { in hierarchical structures. }\end{array}$ \\
\hline Shepard (18) & $\begin{array}{l}\text { Propose that the complexity of } \\
\text { oncological care may require } \\
\text { interventions at various levels to } \\
\text { address moral distress. }\end{array}$ & Editorial & Does not apply. & $\begin{array}{l}\text { Oncology nurses are impacted by the burden of moral } \\
\text { distress and this can affect significantly the care they } \\
\text { offer to patients. Given their pursuit of ethical discussions, } \\
\text { they need professional and administrative support, as } \\
\text { well as guidelines on advanced care to safeguard patient } \\
\text { autonomy. }\end{array}$ \\
\hline $\begin{array}{l}\text { Cohen and } \\
\text { Erickson (17) }\end{array}$ & $\begin{array}{l}\text { Present ethical agreements in nursing, } \\
\text { as well as the situations in which } \\
\text { oncology nurses confront ethical } \\
\text { dilemmas. }\end{array}$ & Editorial & Does not apply. & $\begin{array}{l}\text { Although the oncology area has unidentified ethical } \\
\text { dilemma, scarcity of physical resources and staff, nurses } \\
\text { can improve their practice environment, becoming } \\
\text { examples to other nurses, as well as communication with } \\
\text { the rest of the work staff. }\end{array}$ \\
\hline $\begin{array}{l}\text { Jodoin et al. } \\
\qquad(36)\end{array}$ & $\begin{array}{l}\text { Reflect on the impact of moral distress } \\
\text { in caring for patients. }\end{array}$ & Reflection & Does not apply & $\begin{array}{l}\text { Reflection is important along with the safe space to discuss } \\
\text { thoughts and feelings of nurses to mitigate moral distress } \\
\text { and, thus, be able to provide quality care to the following } \\
\text { patients and their families. }\end{array}$ \\
\hline Pelton et al. (37) & $\begin{array}{l}\text { Describe the approaches used to } \\
\text { alleviate moral distress of nurses } \\
\text { in a surgical oncology unit and the } \\
\text { challenges faced when addressing the } \\
\text { complex factors contributing to that } \\
\text { moral distress. }\end{array}$ & Reflection & 34 oncology nurses. & $\begin{array}{l}\text { Three areas were identified as necessary to improve: } \\
\text { communication, education, and self-care in healthcare. }\end{array}$ \\
\hline
\end{tabular}

Source: authors' elaboration. 
From the critical analysis of the articles selected, it was possible to establish the factors that, according to the literature, favor the emergence of moral distress in oncology nurses (Table 2).

Table 2. Factors influencing upon the emergence of moral distress in oncology nurses found in the integrative review

\begin{tabular}{|c|c|c|}
\hline $\begin{array}{c}\text { Organizational } \\
\text { factors }\end{array}$ & $\begin{array}{c}\text { Most-frequent } \\
\text { clinical situations in } \\
\text { oncology }\end{array}$ & $\begin{array}{c}\text { Inter-professional } \\
\text { relations in the } \\
\text { oncology staff }\end{array}$ \\
\hline Ethical climate & Pain management & Poor communication \\
\hline Evasive culture & Information delivery & Power relations \\
\hline Resources for ethics & Futile treatment & $\begin{array}{c}\text { Little trust on the skills } \\
\text { of other professionals }\end{array}$ \\
\hline & $\begin{array}{c}\text { Assistance to the } \\
\text { family and patient in } \\
\text { their process of death }\end{array}$ & \\
\hline
\end{tabular}

Source: Own elaboration.

\section{Organizational factors}

\section{Ethical climate}

Ethical climate refers to those factors in an organization that contribute to the skills of health professionals to identify and deal with ethical issues to provide adequate ethical care (16). A poor ethical climate is described as a trigger of moral distress in physicians and nurses in oncology units and affects inter-professional interaction (16). Likewise, Pavlish et al., point to the need to develop health systems in moral communities where all the members are urged to clear their ethical concerns and to deal with them in a way that promotes trust, shared understanding, and mutual respect (23). The study by Bartholdson et al., on ethical climate shows that a lower percentage of the participants reported having the necessary tools to solve ethical issues, as well as time for reflection and discussion when there were ethical conflicts related with the treatment and care.

According to Maningo-Salinas et al., health staff leaders could influence positively on the inquest of the phenomenon of moral distress in nursing professionals, upon recognizing the situations that produce moral distress (34) and when becoming aware of the impact this phenomenon can have on the team (27).
Similarly, Jodoin et al., highlight the importance of creating an ethical climate; one of the useful strategies in their unit is the creation of ethical rounds (36).

\section{Evasive culture to deal with difficult ethical issues}

According to Pavlish et al., ethical conflicts in oncology are caused by delaying or avoiding difficult conversations about the poor prognosis of the patient or about the end-of-life care. In another study by the same author (29), nurses and other health providers state that ethical questions can damage relations with patients, relatives, and colleagues, which is why they avoid talking about such. The authors found that many health professionals remain silent about ethical concerns until a precipitating crisis occurs, where these matters can no longer be avoided (29).

\section{Resources for ethics}

Lack of resources for ethics, like participation in specialized programs, funding for follow-up, and time for discussion also influence on the emergence of moral distress $(17,27,37)$. Cohen and Erickson propose that the lack of recognition of the ethical dilemma and their appropriate discussion in the team lead to having moral distress; upon this, Sirilla adds that it is necessary to analyze the ethical problem through theoretical approaches that guide nurses (35).

In the study by Pelton et al., nurses and physicians established key words that allowed them to communicate when they disagreed, for example, with respect to a physician's care plan. When these words were mentioned, a discussion was begun in that respect; thus, the physician reported how decisions were made in light of different processes of the disease, and this permitted the nurses to understand the steps of the treatment to facilitate their care role. Additionally, in this study, the participants worked in inter-professional groups, developing solutions for stressing factors in the unit, and this allowed them an emotional bond to open communication opportunities (37).

Training in ethics and in coping with death can benefit nurses by increasing their self-trust in their knowledge about the end of life and on their awareness with respect to moral distress (35). Sirilla recommends starting education during the initial orientation of the practice to ensure that all nurses are aware of the signs and consequences of moral distress (35). 
Lack of time is another resource revealed as a general concern in nurses when dealing with ethical issues. Not addressing the ethical issues related with the treatment and care can trigger moral distress (16). Communication, reflection, and discussion of ethical issues in specific clinical situations allow the opinions to be heard of all the members involved, and this could contribute to better ethical climate in oncology $(16,27)$.

Furthermore, the existence of support groups for the nursing professionals, comprised by other colleagues, can facilitate discussion of difficult cases, provide support and, thus, reduce moral distress (18). The same study suggests that rotation of complex patients may be useful to diminish the individual burden of moral distress (18).

\section{Complex clinical situations}

In the area of oncology, complex clinical situations exist in which ethical aspects arise that have been widely discussed in the literature and which are a common place of current bioethics.

\section{Pain management}

It is a complex situation that causes ethical conflicts among health professionals (34). In diverse studies, participants report that, on occasion, discrepancies exist among the team members with respect to the doses of analgesics that should be administered to a patient $(29,33,34)$. They also indicate that they must follow medical indications that are not aimed at controlling the patient's pain; thereby, this need is postponed (32). Inadequate management of pain is consequential of patient suffering, which can be a source of moral distress for nurses (26), given that providing inadequate care to patients interferes with the good development of their role, which is related with a high intensity of moral distress in these professionals (31).

Pain management is also influenced by cultural aspects: the study conducted by Lebaron et al., in India shows that nurses endure moral distress because they cannot manage their patients' pain due to scarce resources and administrative barriers, which keeps them from acting as they believe is best for patients.

\section{Information delivery}

Oncology patients are subjected to multiple diagnostic and therapeutic procedures for which it is necessary to obtain in- formed consent from the patients or their families. On some occasions, nursing professionals feel they must ignore situations in which patients have no adequate information that ensures a correct process of informed consent $(22,33,38)$.

The study by Luz et al., shows that several of the ethical issues are related with the transmission of information and orientation to patients in relation to their disease (22). Reporting or not to patients and to their relatives is one of the principal ethical dilemmas experienced by nurses, and this can be potentiated by the family's difficulty in perceiving the information $(22,23)$. Oncology patients have doubts about the diagnosis and medical prognosis of the cancer, and that makes nurses act as links between them and other members of the health staff to make sure patients are informed and have clarity about their care (22).

\section{Futile treatments at the end of life}

Shepard and Pavlish et al., demonstrate that, for the majority of nurses, administering an aggressive treatment to oncology patients during the end of their lives is an ethically difficult situation $(18,23)$. Similarly, witnessing the adverse effects of the treatment causes them moral distress, especially when the objective of care is focused on palliative care and not on curative care (28). The study by Lazzarin et al., shows that the situations in which the family wishes to continue with the treatment, although this is not the best for the child, is a circumstance that causes moral distress to the nurses caring for pediatric patients with cancer (33). The study by Pye mentions that for nurses moral conflicts emerge when limits do not exist with respect to the reanimation of patients at the end of their lives (30). Shepard, in turn, indicates that ethical conflicts appear when physicians and the families make decisions that harm the quality of life of the patients (18).

\section{Assistance to patients and their families during the process of death}

A qualitative study found that some of the important ethical conflicts in oncology refer to confronting situations appertaining to end of life, like administering aggressive treatments during this stage (29), responding to the request of suicide assistance by the patient when a bad prognosis is received (34), and delivering inadequate palliative care (30). This prolongs the process of death with unnecessary aggressive care and offers false hope (32). 
Along with these situations, it has been added that many times health providers delay conversations about precarious prognoses or about the treatment at the end of life (29). Remaining silent upon these situations can act as a trigger of moral distress in nurses $(23,29,33)$.

\section{Interpersonal relations in the oncology staff}

\section{Poor communication}

The health staff in oncology is comprised of members from various disciplines, and lack of communication among them lead to important problems being misinterpreted or misunderstood, which could provoke moral distress in its members (37). The qualitative research conducted by Pye indicates that poor communication and scarce dynamics within the team and within the decision-making process can influence the appearance of moral distress in nurses (30). In this regard, Jodoin et al., indicates that respect is fundamental for the opinions of the rest when the different professions do not coincide on what is best for the patient (36).

Inclusion of nurses as equal partners and informed in formal communication and in the deliberation processes is key to prevent moral distress $(23,28,29,32)$. Staff meetings permit clarifying the procedure to follow in relation to the treatment and care plan (35). Discussing ideas, concerns, and feelings that emerge from the complex clinical situation permit diminishing moral distress $(23,32)$ and having better management to provide quality care to other patients (36).

\section{Power relations}

Differences in professional roles involve distinct power relations, and this can be reflected in the perception of a more or less positive ethical climate among the team members (16). Lack of participation in decision making leads to feelings of powerlessness and devaluation in nurses (30); these can believe that they are incapable of solving ethical conflicts, as well as fearing failure when solving them, or not having enough experience, and this will keep them from formulating ethical questions in the interaction with other professionals (17).

In the study by Pavlish et al., nurses report that working in ethically difficult situations requires time and space; however, the care system in oncology, often, sacrifices comprehensive care for care focused on efficiency due to the high demands of care (28). Additionally, some nurses expressed fear of speaking when their own professional or personal perspectives differed from the predominant voices of the medical care team (28).

\section{Trust in the team's competence}

The study carried out by Ameri et al., in Iran (31) shows that working with colleagues or other health care providers who are quite competent to care for oncology patients propitiates the emergence of moral distress. Recognition of inadequate situations related with negligence, lack of preparation, and professional incompetence can lead these professionals to suffer this phenomenon $(22,32,39)$. Added to this are prejudices among the different disciplines: for example, nurses indicate that physicians do not experience moral distress, given that they do not spend sufficient time with patients to have ethical conflicts (27).

\section{Discussion}

Figure 6 links the results from this review in light of the central concepts of the conceptual model of distress proposed by Barlem and Ramos. Said figure demonstrates that the scenario in which the emergence of moral distress is described in nursing professionals is the health institution, particularly the oncology unit, a micro-space of power that frames the health staff caring for cancer patients, as well as the relations developed among its members. This health staff is made up by different professionals, among which there are the nursing professionals. Nursing professionals who work with people with cancer are exposed constantly to complex clinical situations with associated ethical aspects. Besides, in this model, a key aspect is moral sensitivity, which implies having self-critical view to perceive the moral content of the actions, facts and thoughts related with their clinical practice (3) to, thus, become moral agents (40).

Figure 6 lists the triggering factors of moral distress in oncology nurses. First, there are the organizational factors that correspond to the ethical climate, evasive culture, and resources for ethics; these generate the organizational context in which the health staff performs. The institution plays a fundamental role in delivering the resources to develop ethical competences, and these permit nurses to negotiate and confront administrative and relational obstacles. The findings in this review agree with other authors $(41,42)$ who indicate that it is necessary to provide a support environment in the hospitals and to consider strategies to diminish 
moral distress. In the oncology area, nurses report that the principal barriers for an ethical practice to take place are lack of time, absence of physical spaces for debate and support by the institutional leaders and policies that permit the development of an ethical climate, which coincides with the results found in nurses who work in the area of critical care $(8,43)$.

The second factor in Figure 6 is the health staff confronting complex clinical situations, like pain management, information delivery, consideration of a treatment as futile, and assistance to patients and their families during the process of death. These situations can be favorable scenarios for the appearance of moral distress in oncology nurses (44), when these professionals do not participate in decision making in relation to therapeutic actions or when a clash of values occurs between the nurse's perspective and that of other professionals in decision making. This finding is similar to that found in investigations in critical care $(45,46)$, neonatal and pediatric areas $(10,47)$, and is different from that found in emergency units, where other factors exist, like acute technical environment and high demand with insufficient resources (48). The third factor that triggers moral distress (Figure 6) is inter-professional relations in the oncology staff. In oncology, poor communication, differences in power relations, and poor trust in the competence of other professionals are described in this setting. Power relations, according to Barlem and Ramos, are not merely structures or prohibitions, but also consequences of constant and sustained confrontations over time that define the micro-spaces of power. In the case of oncology, the results show that a scarce dynamic exists within the teams, which marks these spaces with diminished participation by the nurses in decision making. Likewise, the relationship of power is manifested in the fear of nurses in dealing with difficult themes because they are afraid of damaging current or future work relations, which agrees with other studies (49).

In this review, power relations defined the space in which the moral deliberation process took place in oncology. In this key stage of the model, the professionals can discuss their own perspective, bearing in mind the visions of the rest of the team members, and this coincides with other authors who have highlighted the importance of the organization of the teams in the development of moral distress (50). When this process is obstructed, moral perspectives are silenced and the consequence is a feeling of powerlessness in the nurses that keeps them from undertaking the actions they perceive as correct. The obstruction triggers a chain of moral distress that includes the sense of impotence, mortification of their own interests and reduction of resistance to the phenomenon of moral distress. This triggers a process of normalization of the situation and of indifference toward the moral problems of the daily practice of oncology nursing.

\section{Conclusions}

The model of moral distress by Barlem and Ramos (3) permits giving flow to the elements presents in the emergence of moral distress and shows how the obstruction of the moral deliberation process and power relations are central elements in the chain of moral distress, by making it possible to link, coherently, the results of this review. Furthermore, it permitted arranging the results of the review in a cohesive diagram that exposes the dynamics of the teams shown by oncology nurses in the distinct articles reviewed. When ethical issues exist in the clinical situations experienced by oncology nurses, and they do not participate in the deliberation process, these can remain hidden and be presented as normal, which diminishes the moral sensitivity of the professionals and the possibility of acting as moral agents. In all, the three factors described are triggers of moral distress in oncology nurses.

The concept of moral distress applied in oncology involves problems related with the growing demand for care by patients and their families, scarcity of human and material resources, scarce organizational support, training in ethics, correct management of the information provided to the family on the patient's treatments, times of reflection and dialogue regarding death, among others, which makes the study of this phenomenon in oncology even more complex.

Finally, in terms of the professional role, it is worth noting that studies are needed to explore physical, psychological, and behavioral manifestations in oncology nurses. Likewise, it would be important to investigate the implications of moral distress in caring for cancer patients. It is fitting to ask why some nursing professionals normalize the contexts in which moral problems develop and give up on moral resilience (51). The answer could be related with factors, like lack of personal skills, the wear caused by negotiating with other professionals, and clinical demands in oncology that take up an important part of the nurses' time.

\section{Conflict of interest: None declared.}

Acknowledgments: The authors thank the School of Nursing at Pontificia Universidad Católica of Chile for providing space to the elaboration of this work. 
Figure 6. Approximation of the review results of the factors that influence upon the emergence of moral distress in oncology nurses to the model by Barlem and Ramos

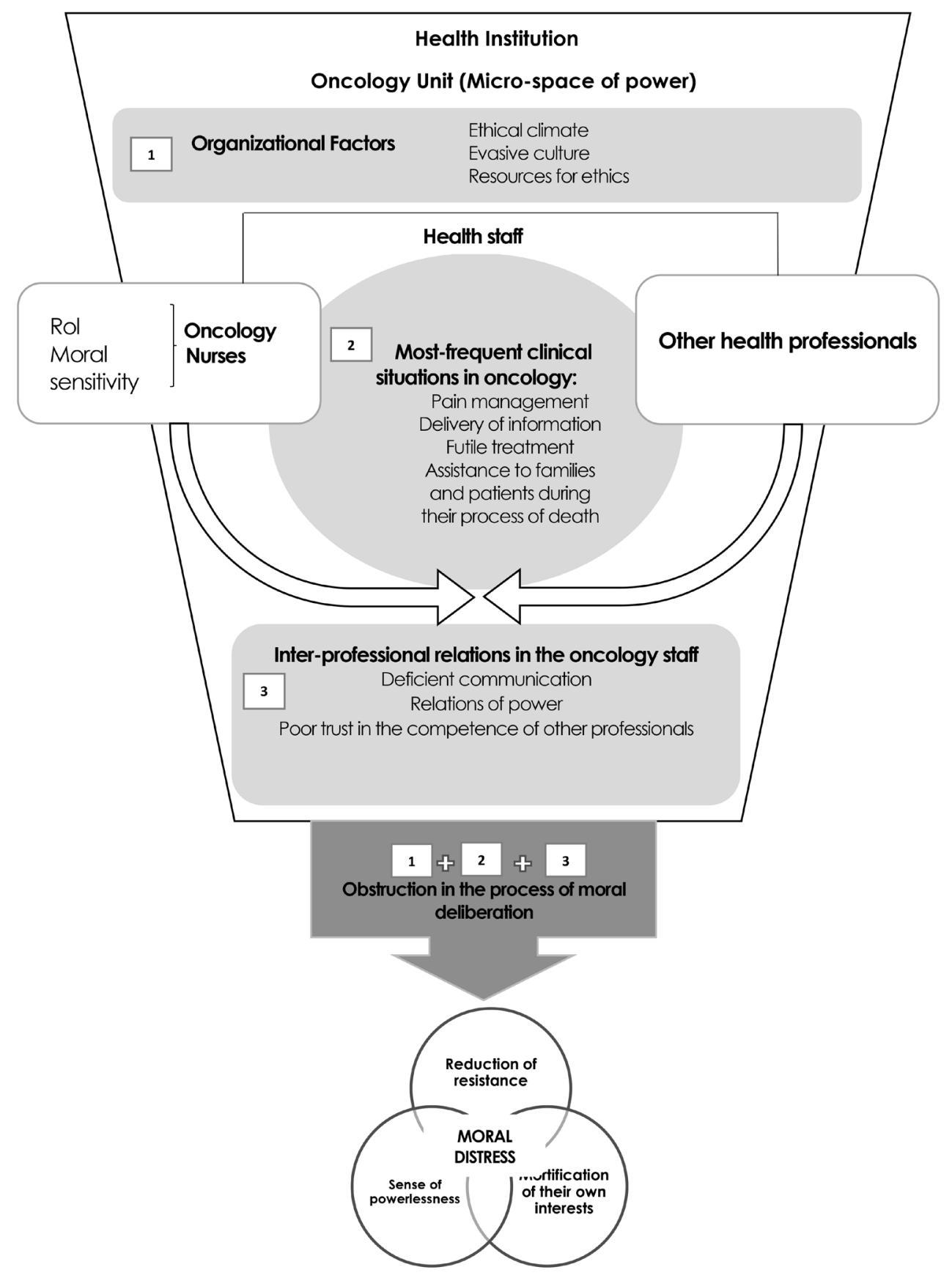

Source: authors' elaboration from the model by Barlem and Ramos (3) 


\section{References}

1. Jameton A. Nursing practice: The ethical issues. Englewood Cliffs: Prentice-Hall; 1984.

2. Kierkegaard S. El concepto de la angustia: una sencilla investigación psicológica orientada hacia el problema dogmático del pecado original. Madrid: Espasa-Calpe; 1967.

3. Barlem ELD, Ramos FRS. Constructing a theoretical model of moral distress. Nurs Ethics. 2015 Aug 22(5):608-615. DOI: $10.1177 / 0969733014551595$

4. Lamiani G, Borghi L, Argentero P. When healthcare professionals cannot do the right thing: a systematic review of moral distress and its correlates. J Health Psychol. 2016 Jul. 10-2017 Jan 22(1):51-67. DOI: 10.1177/1359105315595120

5. Oh Y, Gastmans C. Moral distress experienced by nurses: a quantitative literature review. Nurs Ethics. 2015 Feb 22(1):1531. DOI: $10.1177 / 0969733013502803$

6. Woods M. Beyond moral distress: preserving the ethical integrity of nurses. Nurs Ethics. 2014 Mar 21(2):127-8. DOI: $10.1177 / 0969733013512741$

7. Ganz FD, Wagner N, Toren O. Nurse middle manager ethical dilemmas and moral distress. Nurs Ethics. 2015 Feb 22(1):43-51. DOI: 10.1177/0969733013515490

8. McAndrew N, Laske J, Schroeter K. Moral distress in critical care nursing: the state of the science. Nurs Ethics. 2018 Sep 25(5): 552-570. DOI: 10.1177/0969733016664975

9. Mobley MJ, Rady MY, Verheijde JL, Patel B, Larson JS. The relationship between moral distress and perception of futile care in the critical care unit. Intensive Crit care Nurs. 2007; Oct 23(5):256-63. DOI: 10.1016/j.iccn.2007.03.011

10. Prentice T, Janvier A, Gillam L, Davis PG. Moral distress within neonatal and paediatric intensive care units: a systematic review. Arch Dis Child. 2016 Aug 101(8):701-8. DOI: 10.1136/archdischild-2015-309410

11. Johnstone M-J, Hutchinson A. "Moral distress": time to abandon a flawed nursing construct? Nurs Ethics. 2015 Feb 22(1):5-14. DOI: 10.1177/0969733013505312

12. Rushton $\mathrm{CH}$, Schoonover-Shoffner K, Shawn M. A Collaborative state of the science initiative : transforming moral distress. Am J Nurs. 2017 Feb 117(2):52-6. DOI: 10.1097/01.NAJ.0000512203.08844.1d

13. Morley G, Ives J, Bradbury-Jones C, Irvine F. What is "moral distress"? A narrative synthesis of the literature. Nurs Ethics. 2017 Oct 8;s.d.1-19. DOI: 10.1177/0969733017724354

14. McCarthy J, Gastmans C. Moral distress: a review of the argument-based nursing ethics literature. Nurs Ethics. 2015 Feb 22(1):131-52. DOI: 10.1177/0969733014557139

15. Tigard DW. Rethinking moral distress: conceptual demands for a troubling phenomenon affecting health care professionals. Med Heal Care Philos. 2017 Dec 15;21(4): 479-488. DOI: 10.1007/s11019-017-9819-5

16. Bartholdson C, af Sandeberg M, Lutzen K, Blomgren K, Pergert P. Healthcare professionals' perceptions of the ethical climate in paediatric cancer care. Nurs Ethics. 2016 Dec 23(8):877-88. DOI: 10.1177/0969733015587778

17. Cohen JS, Erickson JM. Ethical dilemmas and moral distress in oncology nursing practice. Clin J Oncol Nurs. 2006 Dec 10(6):775-82. DOI: 10.1188/06.CJON.775-780

18. Shepard A. Moral distress: a consequence of caring. Clin J Oncol Nurs. 2010 Feb 14(1):25-7. DOI: 10.1188/10.CJON.25-27

19. Boyle DA, Bush NJ. Reflections on the Emotional Hazards of Pediatric Oncology Nursing: Four Decades of Perspectives and Potential. J Pediatr Nurs. 2018 May 40:63-73. DOI: 10.1016/j.pedn.2018.03.007

20. Cañadas-De la Fuente GA, Gómez-Urquiza JL, Ortega-Campos EM, Cañadas GR, Albendín-García L, De la Fuente-Solana EI. Prevalence of burnout syndrome in oncology nursing: A meta analytic study. Psychooncology. 2018 May 27(5):14261433. DOI: $10.1002 /$ pon.4632 
21. Neumann JL, Mau LW, Virani S, Denzen EM, Boyle DA, Boyle NJ. et al. Burnout, moral distress, work-life balance, and career satisfaction among hematopoietic cell transplantation professionals. Biol Blood Marrow Transplant. 2018 Apr 24(4):849-60. DOI: 10.1016/j.bbmt.2017.11.015

22. Luz KR da, Vargas MA de O, Schmidtt PH, Barlem ELD, Tomaschewski-Barlem JG, Rosa LM da. Ethical problems experienced by oncology nurses. Rev Latinoam Enferm. 2015 Nov-Dec 23(6):1187-94. DOI: 10.1590/0104-1169.0098.2665

23. Pavlish C, Brown-Saltzman K, Jakel P, Fine A. The nature of ethical conflicts and the meaning of moral community in oncology practice. Oncol Nurs Forum. 2014 Mar 1;41(2):130-40. DOI: 10.1188/14.ONF.130-140

24. Ganong LH. Integrative reviews of nursing research. Res Nurs Health. 1987 Feb 10(1):1-11. DOI: 10.1002/nur.4770100103

25. Urrútia G, Bonfill X. Declaración PRISMA: una propuesta para mejorar la publicación de revisiones sistemáticas y metaanálisis. Med Clin (Barc) [Internet]. 2010 Oct 9 [cited 2018 Dec. 21];135(11):507-11 Retrieved from: https://www. sciencedirect.com/science/article/pii/S0025775310001454?via\%3Dihub

26. LeBaron V, Beck SL, Black F, Palat G. Nurse moral distress and cancer pain management an ethnography of oncology nurses in India. Cancer Nurs. 2014 Sep-Oct 37(5):331-44. DOI: 10.1097/NCC.0000000000000136

27. Lievrouw A, Vanheule S, Deveugele M, Vos M, Pattyn P, Belle V, et al. Coping with moral distress in oncology practice: nurse and physician strategies. Oncol Nurs Forum. 2016 Jul 1;43(4):505-12. DOI: 10.1188/16.0NF.505-512

28. Pavlish C, Brown-Saltzman K, Jakel P, Rounkle A-M. Nurses' responses to ethical challenges. Clin J Oncol Nurs. 2012 Dec 16(6):592-600. DOI: 10.1188/12.CJON.592-600

29. Pavlish C, Brown-Saltzman K, Fine A, Jakel P. A culture of avoidance: voices from inside ethically difficult clinical situations. Clin J Oncol Nurs. 2015 Apr 19(2):159-65. DOI: 10.1188/15.CJON.19-02AP

30. Pye K. Exploring moral distress in pediatric oncology: a sample of registered practitioners. Issues Compr Pediatr Nurs. 2013 Dec 36(4):248-61. DOI: 10.3109/01460862.2013.812693

31. Ameri M, Safavibayatneed Z, Kavousi A. Moral distress of oncology nurses and morally distressing situations in oncology units. Aust J Adv Nurs. 2016 May 33(3):6-11. Available in: http://www.ajan.com.au/Vol33/Issue3/1Ameri.pdf

32. Bohnenkamp S, Pelton N, Reed P, Rishel C. An Inpatient Surgical Oncology Unit's Experience with Moral Distress: Part I. Oncol Nurs Forum. 2015 May 42(3):308-10. DOI: 10.1188/15.ONF.308-310

33. Lazzarin M, Biondi A, Di Mauro S. Moral distress in nurses in oncology and haematology units. Nurs Ethics. 2012 Mar 19(2):183-95. DOI: 10.1177/0969733011416840

34. Maningo-Salinas MJ, Keefer A, Bundy RV, Tiffin C. Relationship between moral distress, perceived organizational support and intent to turnover among oncology nurses. Capella University; 2010.

35. Sirilla J. Moral distress in nurses providing direct care on inpatient oncology units. Clin J Oncol Nurs. 2014 Oct 18(5):536-41. DOI: 10.1188/14.CJON.536-541

36. Jodoin C, Molina E, Filipon K. Alleviating moral distress: a journey to create the most supportive environment. In: Mairead Hickey, Phyllis Beck Kritek, editores. Change leadership in nursing: how change occurs in a complex hospital system. New York: Springer publishing company; 2012. p. 172-4.

37. Pelton N, Bohnenkamp S, Reed PG, Rishel C. An inpatient surgical oncology unit's experience with moral distress: part II. Oncol Nurs Forum. 2015 Jul 42(4):412-4. DOI: 10.1188/15.ONF.412-414

38. Kim K, Han Y, Kim J. Korean nurses' ethical dilemmas, professional values and professional quality of life. Nurs Ethics. 2015 Jun 22(4):467-78. DOI: 10.1177/0969733014538892

39. Bartholdson C, Lützén K, Blomgren K, Pergert P. Experiences of ethical issues when caring for children with cancer. Cancer Nurs. 2015 Mar-Apr 38(2):125-32. DOI: 10.1097/NCC.0000000000000130

40. Carnevale F. Confronting moral distress in Nursing recognizing nurses as moral agents. Rev Bras Enferm. 2013 ; Sep 66 Spec:33-8. DOI: 10.1590/S0034-71672013000700004 
41. Robaee N, Atashzadeh-Shoorideh F, Ashktorab T, Baghestani A, Barkhordari-Sharifabad M. Perceived organizational support and moral distress among nurses. BMC Nurs. 2018 Jan 10;17(2):1-7. DOI: 10.1186/s12912-017-0270-y

42. Haghighinezhad G, Atashzadeh-shoorideh F. Relationship between perceived organizational justice and moral distress in intensive care unit nurses. Nurs Ethics. 2017 Jan 1-11. DOI: 10.1177/0969733017712082

43. Burston AS, Tuckett AG. Moral distress in nursing: contributing factors, outcomes and interventions. Nurs Ethics. 2012 Dec 28-2013 May 20(3):312-24. DOI: 10.1177/0969733012462049

44. Ferrell BR. Understanding the Moral Distress of Nurses Witnessing Medically Futile Care. Oncol Nurs Forum [Internet]. 2006 Sep 1;33(5):922-30. Retrieved from: http://onf.ons.org/onf/33/5/understanding-moral-distress-nurses-witnessing-medically-futile-care

45. Coombs M. Concerns about care and communication are key causes of moral distress in intensive care staff. Aust Crit Care. 2017 Mar 30(2):107-8. DOI: 10.1016/j.aucc.2017.01.007

46. Hiler CA, Hickman RL Jr, Reimer AP, Wilson K. Predictor of moral distress in a US sample of critical nurses. Am J Crit Care. 2018 Jan 27(1):59-66. DOI: 10.4037/ajcc2018968

47. Choe K, Kim Y, Yang Y. Pediatric nurses' ethical difficulties in the bedside care of children. Nurs Ethics. 2017 Jan 1-12. DOI: $10.1177 / 0969733017708330$

48. Wolf LA, Perhats C, Delao AM, Moon MD, Clark PR, Zavotsky KE, et al. "It's a burden you carry": describing moral distress in emergency nursing. J Emerg Nurs. 2016 Jan 42(1):37-46. DOI: 10.1016/j.jen.2015.08.008

49. Pavlish C. Barriers to innovation: nurses' risk appraisal in using a new ethics screening and early intervention tool. Adv Nurs Sci. 2013 Oct-Dec 36(4):304-19. DOI: 10.1097/ANS.0000000000000004

50. Musto LC, Rodney PA, Vanderheide R. Toward interventions to address moral distress: navigating structure and agency. Nurs Ethics. 2015 Feb 22(1):91-102. DOI: 10.1177/0969733014534879

51. Lachman VD. Moral resilience: managing and preventing moral distress and moral residue a case of moral injury and moral distress. Nursing, Med Surg. 2016 Mar-Apr 25(2):121-4. Retrieved from: https://www.ncbi.nlm.nih.gov/ pubmed/27323473 